\title{
Transplantation OF INSULIN-SECRETING Clusters Generated From Mesenchymal Stem Cells To CONTROL INDUCED DIABETES IN RATS
}

\author{
Mohammad El-Nablaway(1), Ahmed Emam(3), Naglaa \\ Mokhtar(1), Osama Elbaz(2), Raymonde Assaf (1), and Amina \\ Baiomy \\ 1) Medical Biochemistry Department, (2) Clinical Pathology \\ Department, (3) Medical Experimental Research Center (MERC), \\ Faculty of Medicine, Mansoura University.
}

Received 21/5/2017- Accepted 20/9/2017

\begin{abstract}
Diabetes mellitus (D.M) is a disease with a high and increasing prevalence. Insulin-producing cells (IPCs) generated from mesenchymal stem cells (MSCs) have shown immense potential for therapy. This study aimed to compare the differentiation potential of 2 kinds of MSCs obtained from human bone marrow (BM), and umbilical cord blood (UCB) into IPCs. In addition, their therapeutic efficiency to control streptozotocin (STZ) - induced diabetic rats was investigated. MSCs were isolated from human BM and UCB, expanded and differentiated to IPCs. The Cells were evaluated by flow cytometry analysis for MSCs markers, RT-PCR for insulin gene expression and ELISA detection of C-peptide release. IPCS were transplanted into the liver of diabetic rats and then evaluated by weekly measurement of the fasting blood glucose (FBG) levels, and detection of in vivo release of C-peptide. This study demonstrated that FBG levels were reduced in diabetic rats transplanted with IPCs, but in rats transplanted with UCB-derived cells were significantly lower than in those transplanted with BM-derived cells. The amount of Cpeptide released from transplanted IPCs derived from BM-MSCs and UCB-MSCs was non-significantly different. The results indicate that UCB- MSCs and BM-MSCs are promising stem cell sources for IPCs that help in the development of a new strategy for treatment of D.M.
\end{abstract}

* Correspondence Author (e mail: : mohammedhelmi679@yahoo.com) 
However, transplantation of IPCs derived from UCB brings better results than BM-derived cells.

\section{INTRODUCTION}

DM is among the most frequent chronic and metabolic disorders (Shaw et al., 2010). The number of people who have DM worldwide has doubled during the past three decades (Chen et al., 2011). In 2010, around 285 million people worldwide had DM, and the number rises to 439 million by 2030 (Zhu et al., 2017). DM can be simply classified into type 1 (T1DM) and type 2 (T2DM) (Yi et al., 2016). T1DM is characterized by the insufficiency of $\beta$-cells as a consequence of autoimmune destruction. There are many therapeutic strategies for TIDM including insulin injection, and pancreas or islet transplantation. Insulin injection mimics $\beta$-cell function, but does not match the precision of functioning $\beta$-cells (Lilly et al., 2016). Islet transplantation has developed a possible therapy for T1DM, but is clinically limited due to lack of donors and immune rejection (Yang et al., 2017). The capacity of stem cells to differentiate into IPCs develops a promising strategy for T1DM therapy (Mishra et al., 2010).

Numerous studies have revealed that embryonic stem cells (ESCs), induced pluripotent stem cells (iPSC), and MSCs are able to differentiate into IPCs (Chandra et al., 2011). ESCs posses the highest differentiation potential to IPCs . However, they have the prospect to create benign cystic teratoma and possible destruction of embryos along the way of collection (El-Badri and Ghoneim., 2013). The application of iPS faces many challenges since the high tumorigenic potential of direct reprogramming caused by genome integration and activation of oncogene c-Myc. MSCs have already been employed in several therapeutic applications as therapy for TIDM because of their immunomodulatory properties, low immunogenicity as a result of lack of major histocompatibility complex II(MHC II), and minimal oncogenic risk(Lilly et al., 2016). MSCs are originated from a diverse variety of tissues as BM, UCB, peripheral blood, adipose tissue, and trabecular bone (Trivanović et al., 2013) .MSCs derived from BM, adipose tissue, UCB, Wharton jelly, and placenta were chosen for differentiation into IPCs (Hashemian et al., 2015). Various studies declare that the generation IPCs from stem cells is achievable and promising. A precise selection 
of stem cell source and differentiation protocol is necessary for a successful IPC generation (Khorsandi et al., 2015).

\section{MATERIALS AND METHODS}

This randomized controlled trial (RCT) was done in Medical Biochemistry Department and Medical Experimental Research Center (MERC), Faculty of Medicine, Mansoura University.

Animal Model: Forty adult Sprague-Dawley rats were purchased from MERC. The rats were divided in a randomized manner into four groups: Group I (Control group) $(n=10)$ : received saline, Group II (Diabetic rats without stem cell transplantation) $(n=10)$, Group III (Diabetic rats with differentiated BM-MSCs transplantation) $(\mathrm{n}=10)$, and Group IV (Diabetic rats with differentiated UCB-MSCs transplantation) $(\mathrm{n}=10)$.

Induction of Diabetes mellitus in the rats: Experimental diabetes was induced by intraperitoneal injection of STZ (Sigma, St. Louis, Missouri, USA) at a dose $60 \mathrm{mg} / \mathrm{kg}$ under light ether anesthesia. The rats fasted for 12 hours. STZ was solubilized in sodium citrate buffer $(\mathrm{pH} 4.5)$ and injected within 15 min of preparation (Akbarzadeh et al., 2007). FBG levels were measured by a blood glucose meter (GlucoDr ${ }^{\mathrm{TM}}$, All Medicus Co. Ltd, Gyeonggi, Korea). Rats were confirmed diabetic when FBG > $200 \mathrm{mg} / \mathrm{dl}$ for 2 consecutive days (Qinna and Badwan, 2015).

Isolation and expansion of human UCB-MSCs and BM-MSCs: UCB samples were obtained from Obstetrics and Gynecology Department, Mansoura University from full-term deliveries.UCB samples were collected in a sterile blood bag containing anticoagulant. BM aspirates (BMA) were obtained from the Clinical Pathology Department, Mansoura University from 2 donors, diagnosed as hypersplenism. The BMA was collected from iliac crest in EDTA. Informed written consents were taken from the donors. The samples were manipulated within $4-6$ hours from the collection at MERC. UCB-MSCs and BM-MSCs were, respectively, isolated in accordance with the protocols described by Divya et al. (2012), Gabr et al. (2013). Briefly, the samples were diluted in 1x phosphate buffer saline (PBS) (Lonza, Walkersville, Inc, USA) in a 1:1 ratio, then the mononuclear cells (MNCs) were separated by Bicoll $(1.077 \mathrm{~g} / \mathrm{ml}$, Biochrome, Berlin, Germany) density gradient centrifugation. The 
MNCs were washed twice in 1x PBS and re-suspended in $20 \mathrm{ml}$ of the proliferation medium consisting of low glucose-Dulbecco's Modified Eagle Media (DMEM) (Lonza), 1\% penicillin- streptomycin (Lonza), $10 \%$ fetal bovine serum (FBS) (Sigma), and 1\% L-glutamine (Lonza). The MNCs were seeded in T75 flasks at a concentration of $5 \times$ $10^{6}$ cells $/ \mathrm{ml}$. After 2-3 days of incubation in a $5 \% \mathrm{CO}_{2}$ incubator at $37^{\circ} \mathrm{C}$, the non-adherent cells were discarded and the adherents MSCs were cultured. After 5-7 days of cultivation, the confluence of cells reached $80 \%$, so the cells were sub-cultured using trypsinization.

Characterization of Isolated MSCs by Flow Cytometry: The cells were incubated with mouse monoclonal antibody against human CD90, CD105, and CD45 (R\&D systems, USA) for 30 minutes at room temperature. Then, washed and Re-suspended in $200 \mu \mathrm{L}$ of PBS. Finally, the cells were stained by incubation with a Phycoerythrin (PE)-conjugated Goat Anti-Mouse secondary antibody (Invitrogen Corporation, Grand Island, NY, USA) for 30 minutes. The stained cells were analyzed using a standard BD Accuri TM C6cytometer and the BD Accuri C6 software (Hu et al., 2013).

Induction of differentiation of BM-MSCs and UCB-MSCs to IPCs: At passage 3, MSCs were cultured in serum-free, high glucoseDMEM $(25 \mathrm{mmol} / \mathrm{L})$ with $0.5 \mathrm{mmol} / \mathrm{L} \beta$-mercaptoethanol (Sigma) for 2 days. Then, the culture medium was changed to serum-free, high glucose medium containing $20 \mathrm{ng} / \mathrm{ml}$ basic fibroblast growth factor (Sigma), 1\% non-essential amino acids (Sigma), 2\% B27 supplement (Gibco BRL, Life Technologies, UK), $20 \mathrm{ng} / \mathrm{ml}$ epidermal growth factor (Sigma), and $2 \mathrm{mmol} / \mathrm{L} \mathrm{L-glutamine} \mathrm{(Sigma)} \mathrm{for} \mathrm{a} \mathrm{further} 8$ days. Finally, the medium was replaced with serum free, high-glucose DMEM containing $10 \mathrm{ng} / \mathrm{ml}$ activin-A (Sigma), $10 \mathrm{ng} / \mathrm{ml}$ betacellulin (Sigma), $10 \mathrm{mmol} / \mathrm{L}$ nicotinamide (Sigma), and 2\% B27 supplement for 8 days (Gabr et al., 2013).

Reverse Transcription- PCR (RT-PCR) for insulin m.RNA expression: Total RNA was extracted from undifferentiated and differentiated cells using TRIzol reagent (Invitrogen Corporation, Grand Island, NY, USA) in accordance with the producer's specifications. The purity of RNA was checked at $260 \mathrm{~nm}$ using NanoDrop 2000 UV-Vis Spectrophotometer (Thermo SCIENTIFIC, USA).First-strand cDNA was generated by using Sensi-FAST ${ }^{\text {TM }}$ c. DNA Synthesis Kit (Bioline, UK).Insulin and Glyceraldehyde-3phosphate dehydrogenase (GAPDH) were amplified using an Applied 132 
Biosystems 2720 thermal cycler (Applied Biosystems, Foster City, CA). Primer sequences were as follows:

\begin{tabular}{|l|l|l|l|}
\hline & Forward primer & Reverse primer & $\begin{array}{l}\text { PCR } \\
\text { product } \\
\text { size }\end{array}$ \\
\hline Insulin & 5 GCAGAAGCGTGGCATTGT 3 & 5 CATCTCTCTCGGTGCAGGAG 3` & 128bp \\
\hline GAPDH & 5 TGCCATGTAGACCCCTTGAA 3 & 5 TGGTTGAGCACAGGGTACTT 3` & $\mathbf{8 6}$ bp \\
\hline
\end{tabular}

The cycle profile was as follows: initial denaturation at $95^{\circ} \mathrm{C}$ for 10 minutes, followed by 35 cycles of denaturation at $95^{\circ} \mathrm{C}$ for $15 \mathrm{~s}$, primer annealing at $60^{\circ} \mathrm{C}$ for $30 \mathrm{~s}$, and extension at $72^{\circ} \mathrm{C}$ for $20 \mathrm{~s}$ ) and the final extension at $72^{\circ} \mathrm{C}$ for 10 minutes. The PCR products were electrophoresed on $3 \%$ agarose gel stained with ethidium bromide and DNA was visualized via light UV Transilluminator (Model TUV20, OWL. Scientific, Inc.800 242-5560).

Glucose challenge test: The IPCs were incubated in DMEM-low glucose $(5.5 \mathrm{mM}$ glucose), and the culture medium was collected. Then, the cells were incubated in DMEM-glucose rich $(25 \mathrm{mM}$ glucose), and then the culture medium was collected. The human Cpeptide concentration was detected in the collected media using Cpeptide ELISA kit (immunospec corporation, Canoga Park, USA) in accordance with the manufacturer's specifications (Tsai et al., 2012).

Transplantation: On the 4th day after STZ injection, the diabetic rats of group II, IV were anesthetized by light ether. The abdominal wall was opened and the liver of diabetic rats was exposed and injected with differentiated UCB-MSCs, BM-MSCs using fine needle syringes in a dose of $2 \times 10^{6}$ cells per injection (Chao et al., 2008). The animals of group I and group II underwent a sham operation. The animals underwent post-operative care including elimination of post-operative pain by analgesic administration and post-surgical infection by antibiotic administration. Approval for these experiments was obtained from the Institutional Research Board (IBR) (Code: PHD/17), Faculty of Medicine, Mansoura University.

Physiological monitoring: For 6 weeks, FBG levels were detected weekly after transplantation using blood glucose meter (GlucoDr ${ }^{\mathrm{TM}}$ ) (Zhou et al., 2015). The blood samples were collected weekly from rats by retro-orbital bleeding. The sera were separated and stored at$20^{\circ} \mathrm{C}$ for determination of human C-peptide concentration using $\mathrm{C}$ peptide ELISA kit (immunospec) (Tsai et al., 2014). 
Statistical analysis: Data were analyzed using the SPSS (Statistics Package for Social Sciences) software program version 17.0. Student's t-test is used for comparison between groups ( $\mathrm{P}$ value of $\leq$ 0.05 was considered significant).

\section{Results}

Morphology and characterization of the cultured MSCs: The undifferentiated BM-MSCs and UCB-MSCs became adherent spindle shaped. The colony formation could be observed approximately at day 10. At the end of differentiation phase, the cells formed spherical clusters, as shown in figure (1). Flow-cytometric analysis showed that they expressed high levels of CD90, and CD105, but negligible levels of CD45, as shown in figure (2). These results revealed that the majority of the cells were MSCs.

There is no apparent difference between BM-MSCs and UCB-MSCs in the rate of growth or differentiation.

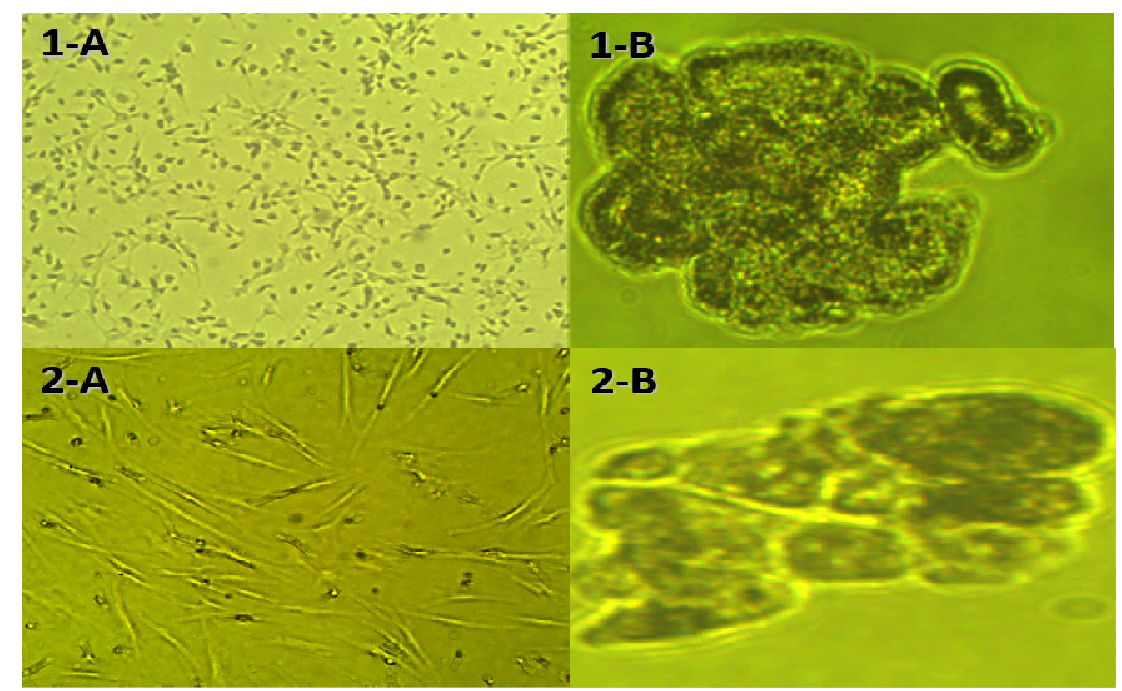

Figure (1): Inverted microscopic picture of 1A) undifferentiated UCB-MSCs at day 10 of culture, 1B) IPCs derived from UCB-MSCs, 2A) undifferentiated BM-MSCs at day 10 of culture, 2B) IPCs derived from BM-MSCs. 

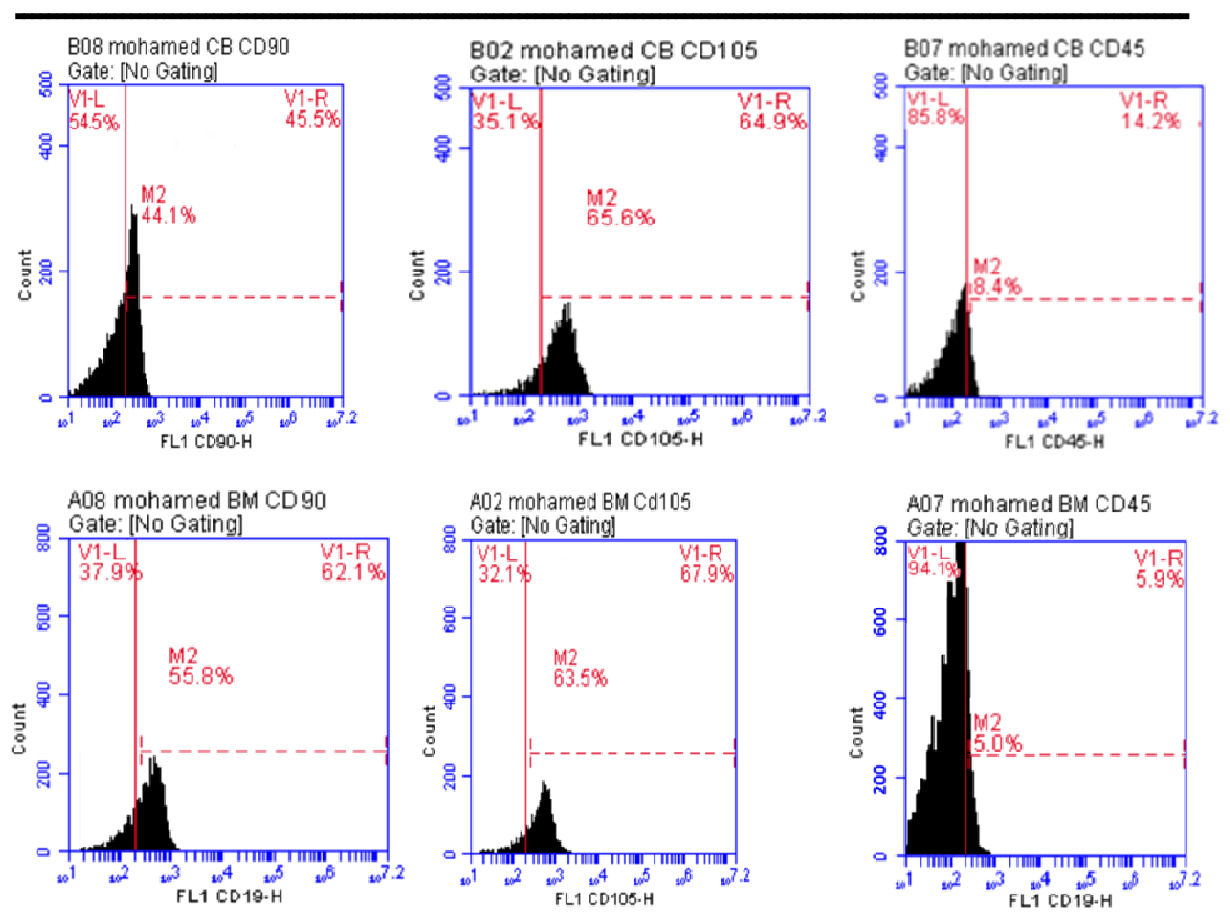

Figure (2): Flow cytometry analysis of UCB and BM-MCS for CD105, CD90 and CD45.Detection of insulin gene expression by RT-PCR: Insulin gene expression was not detected in undifferentiated UCB-MSCs and BMMSCs, but detected in the differentiated cells. The expression of GAPDH gene was detected, as a positive control, as shown in figure (3).

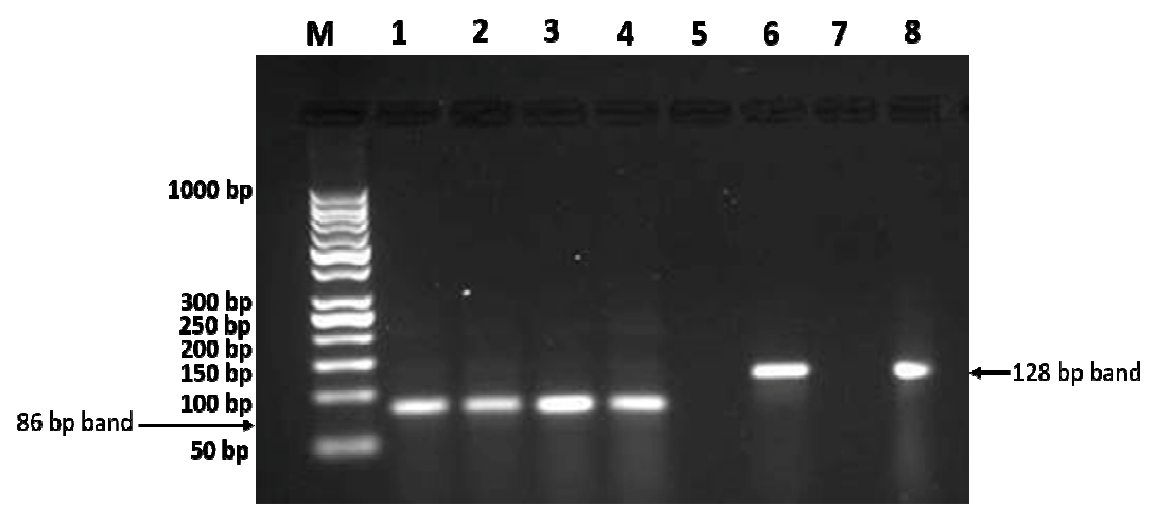

Figure (3): The gel electrophoresis of the RT-PCR products. Lane $(1,5)$ : Undifferentiated UCB-MSCs , lane $(2,6)$ differentiated UCB-MSCs, lane $(3,7)$ : undifferentiated BM-MSCs , lane $(4,8)$ : differentiated BM-MSCs . $\mathrm{M}=: 50 \mathrm{bp}$ DNA ladder .The 128 bp bands represent insulin gene; the $86 \mathrm{bp}$ bands represent the internal control GADPH gene 
In vitro human $\mathrm{C}$-peptide release in response to a glucose challenge: The IPCs derived from BM-MSCs and UCB-MSCs released a significant increase amount of $\mathrm{C}$-peptide at high glucose medium $(25 \mathrm{mM})$ compared to low glucose medium $(5.5 \mathrm{mM})$. There is no significant difference in amount of C-peptide released from BM and UCB-derived cells, as shown in table (1).

Tale (1): C-peptide concentration ( $\mathrm{ng} / \mathrm{ml})$ in low and high glucose culture media.

\begin{tabular}{|l|l|l|}
\hline & $\begin{array}{l}\text { IPCs derived from BM } \\
\text { Mean } \pm \text { SD }\end{array}$ & $\begin{array}{l}\text { IPCs derived from UCB } \\
\text { Mean } \pm \text { SD }\end{array}$ \\
\hline Low glucose medium & $0.35 \pm 0.10$ & $0.37 \pm 0.12$ \\
\hline High glucose medium & $0.84 \pm 0.21$ & $0.84 \pm 0.18$ \\
\hline P1 & $<0.001 * * *$ & $<0.001 * * *$ \\
\hline
\end{tabular}

(SD: standard deviation, P1: significance between low glucose medium\& and high glucose medium).

Outcomes of transplantation: FBG levels in group III, IV is significantly decreased than group II, however in group IV is significantly decreased than group III, as shown in figure (4).There is no significant difference of C-peptide levels in rats`sera released from transplanted IPCs derived from BM and UCB, as shown in table (2).

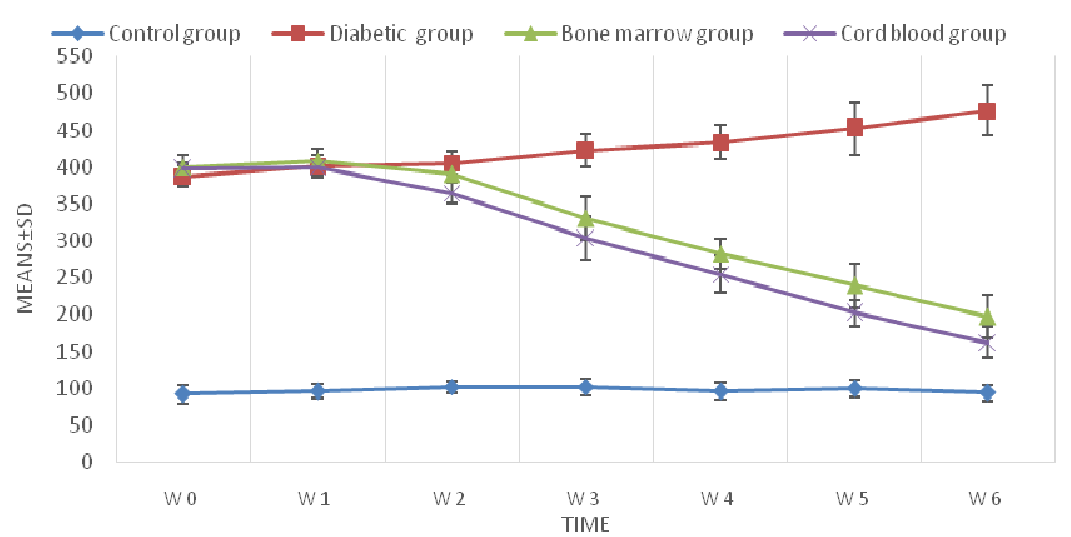

Figure (4): changes in FBG levels among the 4 studied groups. 
Table (2): C-peptide concentration ( $\mathrm{ng} / \mathrm{ml}$ ) in the sera of rats transplanted with IPCs derived from BM-MSCs and UCB-MSCs.

\begin{tabular}{|l|l|l|l|l|}
\hline & $\begin{array}{l}\text { Group I } \\
\text { Mean } \pm \text { SD }\end{array}$ & $\begin{array}{l}\text { Group II } \\
\text { Mean } \pm \text { SD }\end{array}$ & $\begin{array}{l}\text { Group III } \\
\text { Mean } \pm \text { SD }\end{array}$ & $\begin{array}{l}\text { Group IV } \\
\text { Mean } \pm \text { SD }\end{array}$ \\
\hline W0 & $0.65 \pm .15$ & $0.59 \pm .13$ & $0.73 \pm .11$ & $0.74 \pm .08 \mathrm{~b}$ \\
\hline W1 & $0.59 \pm .13$ & $0.67 \pm .18$ & $1.64 \pm .29 \mathrm{a}, \mathrm{b}$ & $1.26 \pm .29 \mathrm{a}, \mathrm{b}, \mathrm{c}$ \\
\hline W2 & $0.44 \pm .10$ & $0.78 \pm .14$ & $2.22 \pm .62 \mathrm{a}, \mathrm{b}$ & $2.04 \pm .51 \mathrm{a}, \mathrm{b}$ \\
\hline W3 & $0.70 \pm .18$ & $0.52 \pm .16$ & $2.32 \pm .53 \mathrm{a}, \mathrm{b}$ & $2.29 \pm 1.09 \mathrm{a}, \mathrm{b}$ \\
\hline W4 & $0.63 \pm .16$ & $0.69 \pm .15$ & $3.55 \pm 1.34 \mathrm{a}, \mathrm{b}$ & $3.77 \pm .97 \mathrm{a}, \mathrm{b}$ \\
\hline W5 & $0.79 \pm .19$ & $0.52 \pm .18$ & $5.56 \pm 1.87 \mathrm{a}, \mathrm{b}$ & $5.12 \pm 2.05 \mathrm{a}, \mathrm{b}$ \\
\hline W6 & $0.54 \pm .14$ & $0.68 \pm .14$ & $7.88 \pm 1.43 \mathrm{a}, \mathrm{b}$ & $6.85 \pm 2.15 \mathrm{a}, \mathrm{b}$ \\
\hline
\end{tabular}

a: significance relative to Group I , b: significance relative to Group II ,c: significance relative to Group III.

\section{DISCUSSION}

Stem cell differentiation to IPCs has become a potential insulin replacement therapy for T1DM. MSCs derived from BM (Gabr et al., 213), and UCB (Parekh et al., 2009) have been used. In previous studies, different cell sources and different differentiation protocols were applied. The present study compared the differentiation potential of MSCs derived from BM and UCB using the same differentiation protocol which was carried out in accordance with Gabr et al., (2013). In the present research, high glucose DMEM media were used. High glucose concentration was a strong stimulus for pancreatic islet differentiation (Bonner-Weir et al., 1989). $\beta$-mercaptoethanol was added to induce expression of transcription factor called pancreatic/duodenal homeobox-1 protein 1(PDX-1) (Wu et al., 2007). PDX-1 is a major regulator of transcription in $\beta$ cells. It activates the insulin gene by binding to its promoter region (Pedica et al., 2014). Fibroblast and epidermal growth factors were used to stimulate proinsulin biosynthesis (Chatterjee et al., 1986) and to play role in clustering of IPCs (Wong ., 2011). Activin A is a member of the transforming growth factor-beta (TGF- $\beta$ ). It was added as it is important for islet development by increasing its insulin content. Betacellulin is a member of epidermal growth factor family. It was used as it helps in regulating the growth of pancreatic endocrine precursor 
cells (Demeterco et al., 2000). Nicotinamide is an effective inducer to maintain islet viability (Kolb and Burkart., 1999). The B-27 supplement was utilized as it contains several components including retinoic acid, insulin and triiodothyronine which support islet cell function and survival (Phelps et al., 2017).

This study revealed that BM and UCB-derived cells were negative for CD45, which indicates that they were not hematopoietic stem cells and positive for CD90 and CD105 which indicate that they were MSCs; these findings coincide with Dominici et al., (2006). Insulin gene expression has been shown with RT-PCR in the differentiated cells. The IPCs were able to secrete c-peptide in larger amounts in response to high glucose concentration in the medium. Transplantation of $2 \times 10^{6}$ IPCs was sufficient to control hyperglycemia in diabetic rats; this finding coincides with Tsai et al., (2012). Fu et al. (2006) showed that no rejections occur after xenotransplantation of differentiated UCB- MSCs without immunosuppression therapy. In the present study, the liver was used as a site for transplantation of IPCs following the protocol conducted by Chao et al. (2008). The liver is the most reasonable choice as it is more accessible than the pancreas, and $\beta$-cells can produce insulin well in that environment. Hepatocytes and $\beta$-cells possess glucosesensing systems, helping them to respond to changes in blood glucose levels (Yang ., 2006).

The significant decrease in FBG levels in diabetic rats after transplantation with UCB and BM -derived IPCs coincide with Chao et al., (2008) and Tsai et al., (2014), However, at the end of the present experiment, the FBG levels were higher than control values, these finding coincide with Tsai et al., (2014) but don't coincide with Chao et al., (2008). This may be explained by the difference in the site of transplantation, or the dose of cells. UCB-derived cells had higher ability to control hyperglycemia in rats in comparison to those derived from BM. To determine whether the transplanted IPCs could control hyperglycemia independently of the rat endogenous pancreatic $\beta$ cells; the human $\mathrm{C}$-peptide levels in serum of experimental rats were estimated. The study showed that the IPCs secreted measurable amounts of C-peptide, this finding coincides with previous report of human adipose tissue derived-MSCs (Chandra et al., 2011). However, the amount of $C$-peptide secreted from IPCs derived $\mathrm{BM}$ and UCB was not significant different . 
Conclusion

These results suggest that BM-MSCs and UCB-MSCs are a promising cell source for regenerative therapy in TIDM. However, control of hyperglycemia using UCB-derived IPCs was significantly better than BM-derived IPCs. Further study is needed to investigate their curative effects in larger diabetic animal models and to through the light for its future clinical application.

\section{REFERENCES}

Akbarzadeh. A., Noruzian. D., Jamshidi. S., Farhangi. A., Mehrabi. M.R., Rad. B.L., Mofidian. M. and Allahverdi. A. (2007): Treatment of streptozotocin induced diabetes in male rats by immune-isolated transplantation of islet cells. Indian J Clin Biochem, 22(1):71-6.

Bonner-Weir. S., Deery. D., Leahy. J.L., and Weir. G.C.(1989): Compensatory growth of pancreatic beta-cells in adult rats after shortterm glucose infusion. Diabetes, 38(1):49-53.

Chandra. V., Swetha. G., Muthyala. S., Jaiswal. A.K, Bellare JR, Nair. P.D., and Bhonde. R.R (2011): Islet-like cell aggregates generated from human adipose tissue derived stem cells ameliorate experimental diabetes in mice. PLoS One, 6 (6): e20615.

Chao. K.C,Chao. K.F , Fu. Y.S and Liu. S.H. (2008): Islet-Like Clusters Derived from Mesenchymal Stem Cells in Wharton's Jelly of the Human Umbilical Cord for Transplantation to Control Type 1 Diabetes. PLoS ONE, 3 (1): e1451.

Chatterjee. A.K., Sieradzki. J., and Schatz.H. (1986): Epidermal growth factor stimulates (pro-) insulin biosynthesis and 3H-thymidine incorporation in isolated pancreatic rat islets. Horm Metab Res, 18 (12): 873-874.

Chen. L., Magliano. D.J., and Zimmet. P.Z. (2011): The worldwide epidemiology of type 2 diabetes mellitus-present and future perspectives. Nat Rev Endocrinology, 8 (4): 228-36.

Demeterco. C.1., Beattie. G.M., Dib SA, Lopez. A.D., Hayek. A. (2000): A role for activin A and betacellulin in human fetal pancreatic cell differentiation and growth. J Clin Endocrinol Metab. , 85(10):3892-7.

Divya. M.S., Roshin. G.E., Divya. T.S., Rasheed. V.A., Santhoshkumar. T.R., Elizabeth. K.E., James. J., and Pillais R.M. 
(2012): Umbilical cord blood-derived mesenchymal stem cells consist of a unique population of progenitors co-expressing mesenchymal stem cell and neuronal markers capable of instantaneous neuronal differentiation. Stem Cell Research \& Therapy, 3(6), 57.

Dominici. M., LeBlanc. K., Mueller I., Slaper-Cortenbach I., Marini. F., Krause. D., Deans. R., Keating. A., Prockop. D.j., and Horwitz. E. (2006): Minimal criteria for defining multipotent mesenchymal stromal cells. Cytotherapy, 8 (4): 315-317.

El-Badri. N. and Ghoneim. M.A. (2013):Mesenchymal Stem Cell Therapy in Diabetes Mellitus: Progress and Challenges. J Nucleic Acids,ID 194858: 1-7.

Fu.Y.S., Cheng.Y.C., Lin. M.Y., Cheng. H., Chu. P.M (2006): Conversion of human umbilical cord mesenchymal stem cells in wharton's jelly to dopaminergic neurons in vitro: Potential therapeutic application for parkinsonism. Stem Cells, 24:115-124.

Gabr. M.M., Zakaria. M.M., Refaie. A.F., Ismail. A.M., Abou-ElMahasen. M.A., Ashamallah. S.A., Khater. S.M., El-Halawani. S.M., Ibrahim. R.Y., Uin. G.S., Kloc. M., Calne. R.Y., and Ghoneim. M.A. (2013): Insulin-Producing Cells From Adult Human Bone Marrow Mesenchymal Stem Cells Control Streptozotocin-Induced Diabetes in Nude Mice .Cell Transplantation, 22: 133-145.

Hashemian. S.J., Kouhnavard. M., and Nasli-Esfahani. E. (2015): Mesenchymal Stem Cells: Rising Concerns over Their Application in Treatment of Type One Diabetes Mellitus. Journal of Diabetes Research, 2015:ID675103.

Hu. L., Hu. J., Zhao. J., Liu. J., Ouyang. W.,Yang. C., Gong. N., Du. L., Khanal. A., and Chen. L. (2013): Side-by-Side Comparison of the Biological Characteristics of Human Umbilical Cord and Adipose Tissue-Derived Mesenchymal Stem Cells. BioMed Research International, 2013, ID 438243.

Khorsandi. L., Khodadadi. A., Nejad-Dehbashi. F.,and Saremy. S. (2015):Three-dimensional differentiation of adipose-derived mesenchymal stem cells into insulin-producing cells. Cell and tissue research, 361(3), 745-753.

Kolb. H. and Burkart. V. (1999): Nicotinamide in type 1 diabetes (1999): Mechanism of action revisited. Diabetes Care, 22 (2): 18-20.

Lilly. M.A., Davis. M.F., Fabie. J.E., Terhune. E.B. and Gallicano. G.I. (2016): Current stem cell based therapies in diabetes. American Journal of Stem Cells, 5 (3): 87-98. 
Mishra .P.K., Singh. S.R., Joshua. I.G. and Tyagi. S.C. (2010): Stem cells as a therapeutic target for diabetes. Front Biosci, 1 (15): 461477.

Parekh. V.S., Joglekar. M.V. and Hardikar AA (2009): Differentiation of human umbilical cord blood-derived mononuclear cells to endocrine pancreatic lineage.Differentiation,78(4): 232-240.

Pedica. F., Beccari. S., Pedron. S., Montagna. L., Piccoli. P., Doglioni. C., and Chilosi. M.(2014): PDX-1 (pancreatic/duodenal homeobox-1 protein1). Pathologica. , 106(4):315-21.

Phelps. E.A., Cianciaruso. C., Santo-Domingo. J., Pasquier. M., Galliverti. G., Piemonti. L., Berishvili. E., Burri. O., Wiederkehr. A., Hubbell. J.A., and Baekkeskov. S. (2017): Advances in pancreatic islet monolayer culture on glass surfaces enable super-resolution microscopy and insights into beta cell ciliogenesis and proliferation. Sci Rep., 7:45961.

Qinna. N.A and Badwan. A.A.(2015): Impact of streptozotocin on altering normal glucose homeostasis during insulin testing in diabetic rats compared to normoglycemic rats. Drug Design, Development and Therapy, 9:2515-25.

Shaw. J.E., Sicree. R.A. and Zimmet. P.Z. (2010): Global estimates of the prevalence of diabetes for 2010 and 2030. Diabetes research and clinical practice, 87(1):4-14.

Trivanović. D., Kocić. J., Mojsilović. S., Krstić. A., Ilić. V.,Djordjević. I.O., Santibanez. J.F., Jovcić. G., Terzić. M. and Bugarski. D. (2013): Mesenchymal stem cells isolated from peripheral blood and umbilical cord Wharton's jelly. Srp Arh Celok Lek, 141(3-4):178-86.

Tsai. P.J., Wang. H.S., Shyr. Y.M., Weng. Z.C., Tai. L.C., Shyu. J.F., and Ti Chen. T.H. (2012): Transplantation of insulin-producing cells from umbilical cord mesenchymal stem cells for the treatment of streptozotocin-induced diabetic rats. Journal of Biomedical Science, 19:47.

Tsai. P.J., Wang. H.S., Lin. C.H.,Weng. Z.C., Chen. T.H. and Shyu. J.F. (2014): Intraportal injection of insulin-producing cells generated from human bone marrow mesenchymal stem cells decreases blood glucose levels in diabetic rats. Endocr Res, 39 (1): 26-33. 
Wong. R.Y. (2011): Extrinsic Factors Involved in the Differentiation of Stem Cells into Insulin-Producing Cells: An Overview; Experimental Diabetes Research: 2011, ID 406182.

Wu. X.H., Liu. C.P., Xu. K.F., Mao. X.D., Zhu. J., Jiang. J.J., Cui. D., Zhang. M., Xu. Y., and Liu. C. (2007): Reversal of hyperglycemia in diabetic rats by portal vein transplantation of isletlike cells generated from bone marrow mesenchymal stem cells. World J Gastroenterol., 13(24):3342-3349.

Yang. L.J. (2006): Liver stem cell-derived beta-cell surrogates for treatment of type 1 diabetes.

. Autoimmun Rev., 5(6):409-13.

Yang. X.F., Chen. T., Ren. L.W., Yang. L., Qi. H. and Li. F.R. (2017): Immunogenicity of insulin-producing cells derived from human umbilical cord mesenchymal stem cells. Experimental and Therapeutic Medicine, 13 (4): 1456-1464.

Yi. B., Huang. G., and Zhou. Z. (2016): Different role of zinc transporter 8 between type 1 diabetes mellitus and type 2 diabetes mellitus. J Diabetes Investig., 7(4):459-65.

Zhou. Y., Hu. Q., Chen. F., Zhang. J., Guo. J., Wang. H., Gu. J., Ma. L. and Ho. G. (2015): Human umbilical cord matrix-derived stem cells exert trophic effects on $\beta$-cell survival in diabetic rats and isolated islets. Disease Models \& Mechanisms, 8(12):1625-1633.

Zhu. B., Wu. X., Wu. B., Pei. D., Zhang. L., and Wei. L. (2017): The relationship between diabetes and colorectal cancer prognosis: A meta-analysis based on the cohort studies. PLoS one, 12(4): e0176068. 


\section{الملخص العربي}

انتاج تجمعات مفرزة للأنسولين من الخلايا الجذعية الطولية للتحكم في داء البول السكرى لاى الفئران. محمد النبلاوى(")، أحمد امام(")، نجلاء مختار (")، أسامة الباز (")،يمونده عساف(")، أمينة بيومي (1) (1) قسم الكيمياء الحيوية الطبية،(ץ) قسم الباثولوجيا الإكلينيكية(ب) مركز البحوث الطبية التجريبية - كلية الطب -جامعة المنصورة. إن الاصابة بمرض البول السكرى في ارتفاع وانتثار متزايد. وقد أظهر استخدام الخلايا

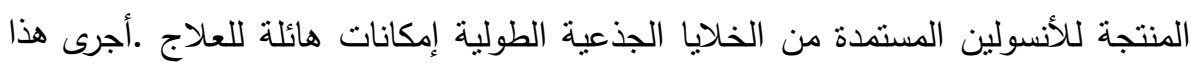

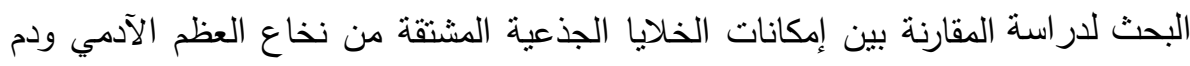

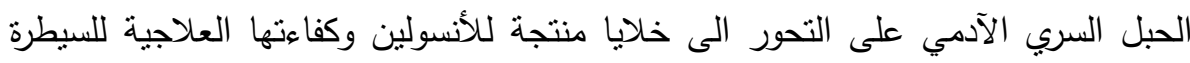
على داء البول السكرى لاى الفئران.

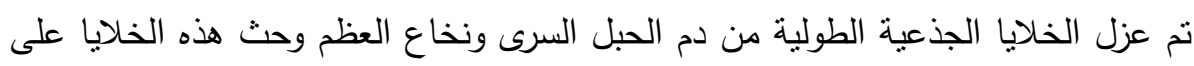

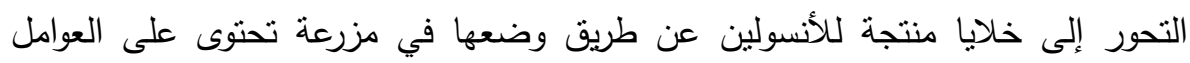

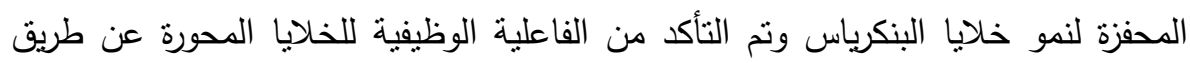

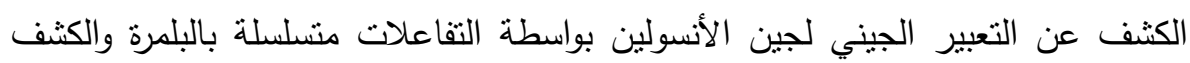

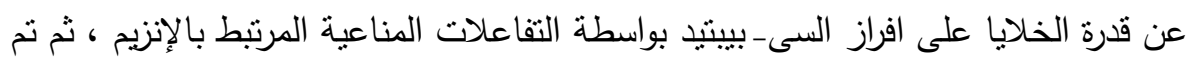

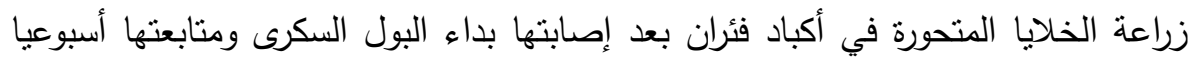

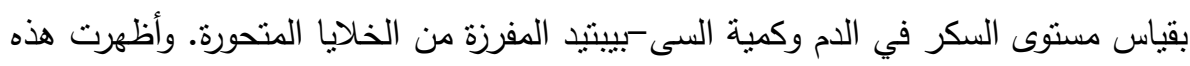

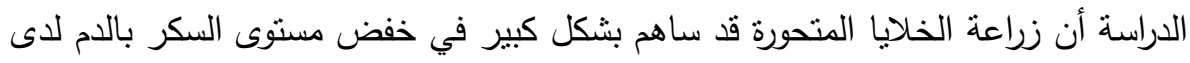

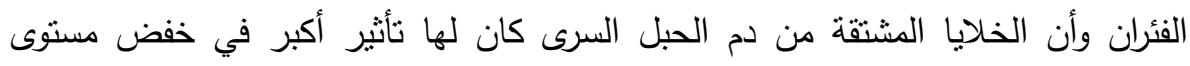

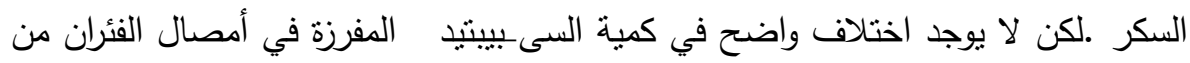
الخلايا المشتقة من دم الحبل السرى بالمقارنة بالخلايا المشتقة من نخاع العناع العظم.

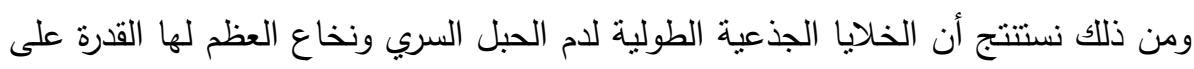

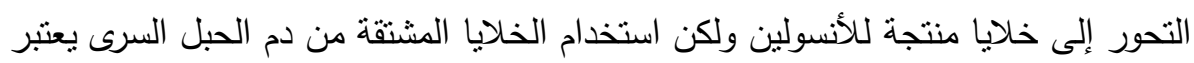

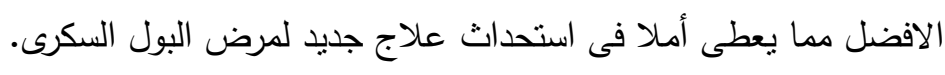

